\title{
DYNAMICS OF VARIATION IN PHYSICAL CAPACITY OF ELDERLY PEOPLE
}

\author{
Lina Kreivènaitė, Vytautas Streckis, Kristina Visagurskienė, \\ Alfonsas Buliuolis, Asta Lileikienè \\ Lithuanian Sports University, Kaunas, Lithuania
}

\begin{abstract}
Research background and hypothesis. Increase in physical capacity and fitness can lead to additional improvements in health status, which is so important for healthy aging. Most scientists emphasize the physical activity decline in people of all ages. Therefore, it is important to assess health-related physical capacity and encourage people of various ages to improve their health, physical fitness and the quality of their life. Hypothesis - a significant decline in physical capacity of the elderly will be identified during the research period.

Research aim - to identify the variation dynamics of physical capacity indices of elderly people.

Research methods. 60-69-year-old males and females were selected for the data analysis $(\mathrm{n}=244)$. The anthropometric data and the physical capacity test results of trunk flexion, sit ups, balance and 1000 meter run were analysed. Physical capacity tests were carried out on the basis of the 'Eurofit' test methodology. The methods of descriptive statistics were used for the data analysis.

Research results. Body balance (43.8\%) and aerobic capacity (20.8\%) of the elderly males significantly declined $(\mathrm{p}<0.05)$ during the experimental period. However, improvement in the flexibility of males $16.5 \%(\mathrm{p}<0.05)$ was identified. The capacity of trunk flexor muscles of elderly females improved significantly by $39.3 \%$, while the balance - by $18.1 \%(p<0.05)$. Analysis of the results in reference to gender showed that the balance, the capacity of trunk flexor muscles and aerobic capacity of elderly females increased significantly in comparison with males $(p<0.05)$. Nevertheless, the flexibility variation of males was higher than the one of females $(p<0.05)$ at the end of the research period.

Discussion and conclusions. The balance and aerobic capacity of elderly males significantly decreased, whereas the flexibility improved. The capacity of trunk flexor muscles and balance of elderly females resulted in a statistically significant increase. In reference to the gender aspect it was determined that the majority of physical capacity results of elderly females statistically significantly developed more than the physical capacity results of males.
\end{abstract}

Keywords: physical capacity, elderly people, 'Eurofit'.

\section{INTRODUCTION}

$\mathrm{A}$ $\mathrm{t}$ different stages of human life, movement is an integral mechanical and biological process which is monitored by special educational programs and regulations of different sports (Kowalski et al., 2012). The content and forms of sports movement are determined by age, gender and needs (Warburton, Bredin, 2006). Human movement, especially one of elderly people, is a component of an educational system that encourages their social participation, self- expression, self-development, value system, quality of life and healthy ageing by reducing the risk of age-related diseases (Warburton, Bredin, 2006; Xue et al., 2012; Dale et al., 2013; Hobbs et al., 2013). Most scientists emphasize the physical activity decline in people of all ages (Bouchard, Rankinen, 2001; Doherty, 2003; Fitts, 2008). In addition, the authors note that physical activity, even below the recommended level, is directly related to the longer 
maintenance of physical fitness and a lower risk of death in early old age (Xue et al., 2012) .

It is observed that more people are engaged in monotonous work activity requiring repeated muscle contractions or prolonged abnormal postural maintenance (Bouchard et al., 2001; Doherty, 2003). Such activities increase local muscle fatigue and even the risk of injuries, promote earlier physical fitness decline, fatigue, senile diseases (Warburton, Bredin, 2006; Xu, Murrell, 2008; Stone et al., 2010).

Most of the fatigue tests are based on muscle strength or capacity measurements during the performance of high-intensity exercises. The ability to activate skeletal muscles can add much importance to fatigue during this kind of exercises (Gandevia, 2001)It is believed that increasing physical activity of the elderly can delay the fatigue originating in central and peripheral nervous systems (Doherty, 2003; Selen et al., 2007; Gates, Dingwell, 2008). But, the effect of physical activity of the elderly on their health and capacity improvement as well as changes in the physical capacity of older people in prolonged period of time have not been fully investigated yet and remain unclear. The problem of how to assess the fitness of the elderly still stays unsolved (Kowalski et al., 2012). Therefore, the hypothetical assumption may be held that a significant decline in physical capacity of the elderly will be identified during the research period. The purpose of the research: to identify the variation dynamics of physical capacity of elderly people.

\section{RESEARCH METHODS}

Subjects. 244 elderly subjects volunteered to participate in this study. The participants were healthy, leading similar lifestyle, physically active elderly males and females, ranging from 60 to 69 years of age (anthropometric characteristics are presented in Table). Each subject read and signed a written informed consent form that was consistent with the principles outlined in the Declaration of Helsinki.

Physical capacity tests. For the assessment of physical capacity the methodology of the Eurofit test (Volbekiene, Kavaliauskas, 2002) was applied. We analysed the results of the following tests: trunk flexion, sit up, balance and 1000 meter run:

a) Trunk flexion test - the assessment of trunk movement capability. Technical measures: a chair, a ruler. Instructions: an initial position - sitting on a chair, one leg stretched out in the front, the other leg, as usual, bent at a right angle. A performer has to reach the stretched big toe with his one hand and continue. A performer has to place his feet as much as possible in front of himself. Trunk flexion is measured by a ruler's zero mark added to the top of the middle finger to the big toe of the foot. Results of the test are expressed by centimeters.

b) Sit up test - the assessment of abdominal muscle endurance. Technical measures: a mattress, a timer, an assistant. Instructions: a performer has to sit on a mattress with a straight back, hands spliced behind the head, legs bent at the knees at the angle of 90 degrees, the soles of feet rest on the mattress. During the test a performer has to lie down on his back, the shoulders have to touch the mattress, and then return to a sitting position so that the elbows touch the knees. After the command 'go' a performer has to repeat the exercise as many times as he can. The test is carried out in 30 seconds. The result of the test is expressed by repeats per 30 seconds.

c) Balance test - the level of overall body balance and motor capacity are assessed. Technical measures: a timer, a special metal turnpike. Instructions: a performer stands barefoot on a turnpike (according to its longitudinal axis) on one foot, trying to maintain stability as long as he can. If stability is lost and a performer touches the ground with the other foot, the time of the test is stopped. A performer gets one penalty point. When a performer takes the initial position he can continue the test and time is counted further. The test is carried out in 30 seconds. The result of test is expressed by penalty points per 30 seconds.

d) 1000 meter run test - the assessment of aerobic capacity. Technical measures: an indoor stadium, a timer. Instructions: 25 participants stand 1 meter behind the start line. After the command 'on your marks' participants hold their positions at the start line. After the command 'go' participants start to complete the course as quick as they can. The result is expressed by minutes.

Experimental protocol. All subjects completed a form about their health condition before participating in the experiment. Then anthropometric measurements (height, weight) were carried out. After the initial measurements had been done, the participants performed the warm-up by themselves and then performed 


\begin{tabular}{|c|c|c|c|c|c|c|c|}
\hline \multicolumn{2}{|c|}{ Group } & Subjects, $n$ & Age, yrs & Height, $\mathrm{cm}$ & Weight, kg & BMI & of subjects. Values are means \\
\hline Males & $\begin{array}{l}\text { Mean } \\
\text { (SD) }\end{array}$ & 114 & $\begin{array}{l}64,3 \\
(4.9)\end{array}$ & $\begin{array}{l}171.6 \\
(4.7)\end{array}$ & $\begin{array}{l}73.4 \\
(5.1)\end{array}$ & $\begin{array}{l}24.6 \\
(3.1)\end{array}$ & \\
\hline Females & $\begin{array}{l}\text { Mean } \\
\text { (SD) }\end{array}$ & 130 & $\begin{array}{l}64,5 \\
(4.5)\end{array}$ & $\begin{array}{c}161.3 \\
(5.9)\end{array}$ & $\begin{array}{l}66.6 \\
(4.8)\end{array}$ & $\begin{array}{l}25.9 \\
(5.4)\end{array}$ & \\
\hline
\end{tabular}

physical capacity tests, as described in paragraph 2.2. Before each test, the testees could make several pilot attempts. Among physical capacity tests the subjects rested approximately 10 minutes.

Data and statistical analysis. Data analysis was performed using the Statistical Package for Social Sciences (SPSS), version 17. All the data was expressed as the mean (x), standard deviation (SD) of the mean. The hypothesis concerning the differences among the means were verified using the Student's $t$ test for independent and dependent variables. The differences in the means were regarded as statistically significant when error probability in reference to criteria was $\mathrm{p}<0.05$.

\section{RESEARCH RESULTS}

During the research period the results of elderly males performing the sit up test changed gradually (Figure 1), but the statistically significant change was observed only in 2006 and 2010. In recent years, the results of males' group were better, 15.3 and $19.2 \%$ compared with initial measurements $(p<0.05)$. Meanwhile, the results of females' group changed gradually during the period of investigation. Although the 2006-2009 year results were not significantly important, the statistically significant $14.5 \%$ improvement in performance $(\mathrm{p}<0.05)$ was recorded in 2010 as well as in 2011 $(25.2 \%)$ and $2012(39.3 \%)(\mathrm{p}<0.05)$ (Figure 1). In the gender-specific analysis of the sit-up test data, the results of females' group increased significantly more than those of men's group in 2007-2009 and 2011-2012 ( $\mathrm{p}<0.05)$.

The results of balance test (Figure 2) confirmed that the results of male group significantly worsened $45.6 \%(\mathrm{p}<0.05)$ from 2005 to 2009. Although the results reached the 2005 level in 2010 but decreased repeatedly to $43.8 \%$ $(\mathrm{p}<0.05)$ from 2011 to 2012 in comparison to initial measurements. The change dynamics of balance test results of female group was uneven over the experimental period. In 2006, the recorded balance test result decreased in $26.7 \%$ more than that of the initial investigation in $2005(\mathrm{p}<0.05)$. Although minor changes were noticed during the 2007-2011 period, but the difference between the results of the test at the beginning and end of the tests carried out is statistically significant, and the result of balance improvement was $18.1 \%(\mathrm{p}<0.05)$ in 2012 (Figure 2). The gender-specific analysis revealed that the result dynamics of males' balance test in 2006 was more statistically significant than the one of females $(p<0.05)$ in comparison to initial tests. However, the female's balance results improved significantly during 2007-2009 and 2011-2012

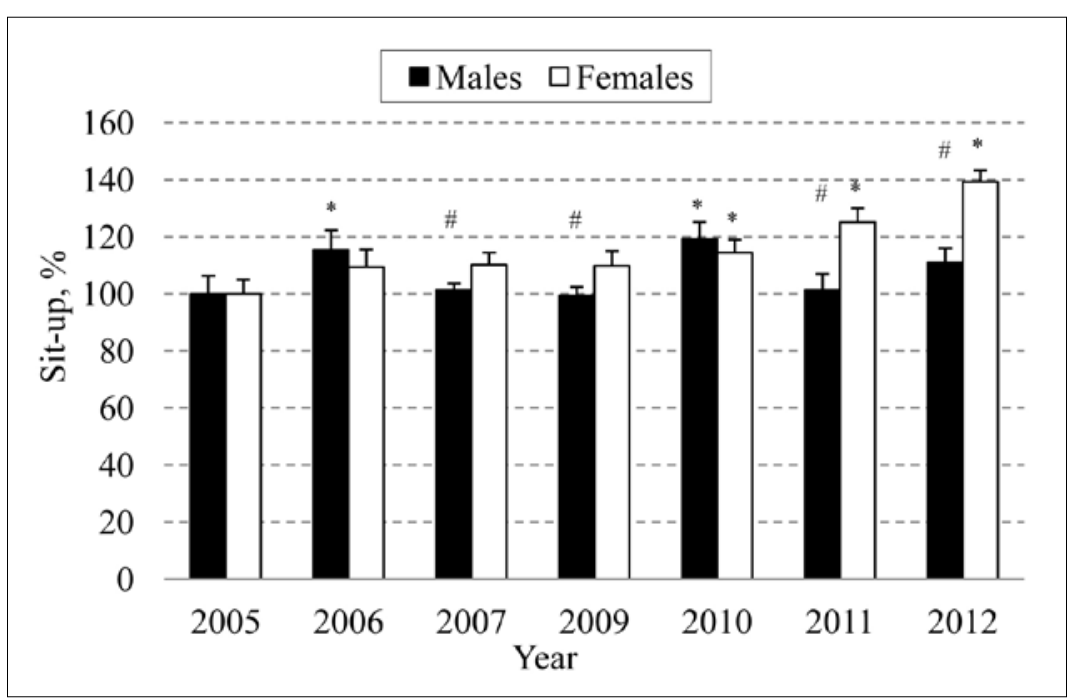

Figure 1. Sit up test results of males and females
Note. ${ }^{*}-\mathrm{p}<0.05$ - compared to initial measurements; \# $-\mathrm{p}<0.05-$ males and females compared. 
years, while those of men declined, leading to a statistically significant difference between the genders $(\mathrm{p}<0.05)$ (Figure 2).

The males' trunk flexion test results (Figure 3) were also statistically unstable during the research period. While the males' results regressed and progressed in time, the subjects' in 2007, 2010 and 2012 , flexibility was significantly bigger $16.5 \%$ than one at the beginning of the testing period in 2005 ( $\mathrm{p}<0.05$ ). Females' flexibility during the period remained stable. As a statistically significant $9.4 \%$ decrease in the results occurred only in 2011 $(\mathrm{p}<0.05)$, no significant change in the results of the dynamics during the period has been established. The gender-specific analysis of the trunk flexion test resulted in the statistically significantly greater improvement in the flexibility of males' group than that of the females $(\mathrm{p}<0.05)$ in $2010-2012$.
After the result analysis of the 1000-meter run test (Figure 4) it was found out that during the experimental period, the total aerobic capacity was associated with statistically significant changes only in the males' group. At the beginning of the research period (2007), males' run test results did not differ significantly from initial measurements (2006). However, the average aerobic capacity of males was significantly reduced by $20.8 \%$ $(p<0.05)$ in 2009 and remained significantly lower in the further experimental period 2010-2012 $(\mathrm{p}<0.05)$. Meanwhile, no significant changes were noticed over the trial period in the 1000-meter run results of females and the results remained at the similar level. Gender analysis revealed that the males' aerobic capacity in 2009-2012 was reduced more significantly than the aerobic capacity of females $(\mathrm{p}<0.05)$.
Figure 2. Balance test results of males and females

Note. ${ }^{*}-\mathrm{p}<0.05-$ compared to initial measurements; \# $-\mathrm{p}<0.05-$ males and females compared.

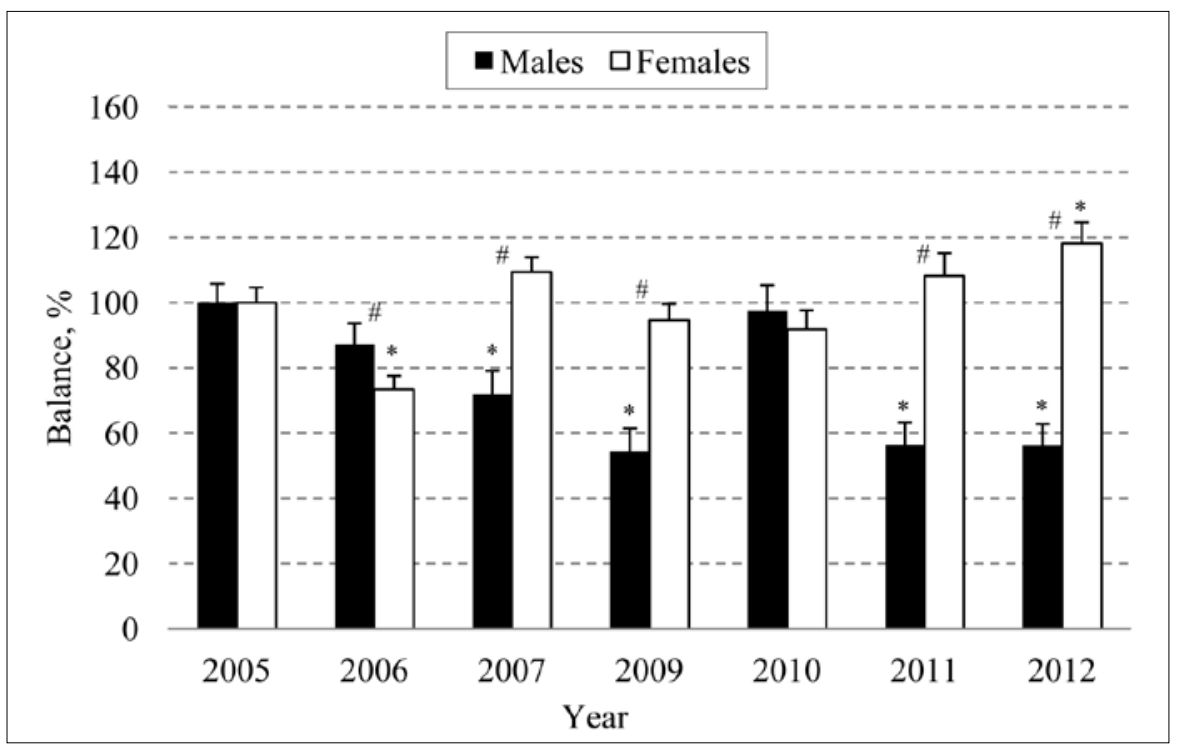

Figure 3. Trunk flexion test results of males and females

Note. ${ }^{*}-\mathrm{p}<0.05$ - compared to initial measurements; $\#-\mathrm{p}<0.05-$ males and females compared.

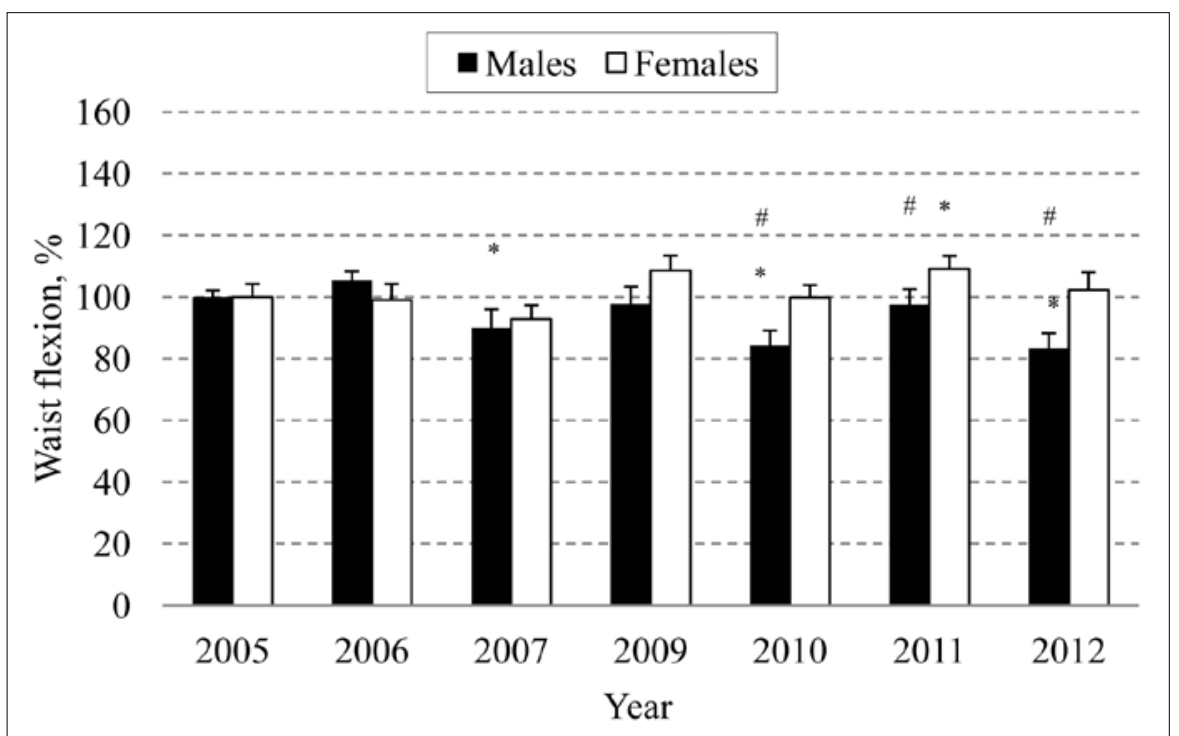




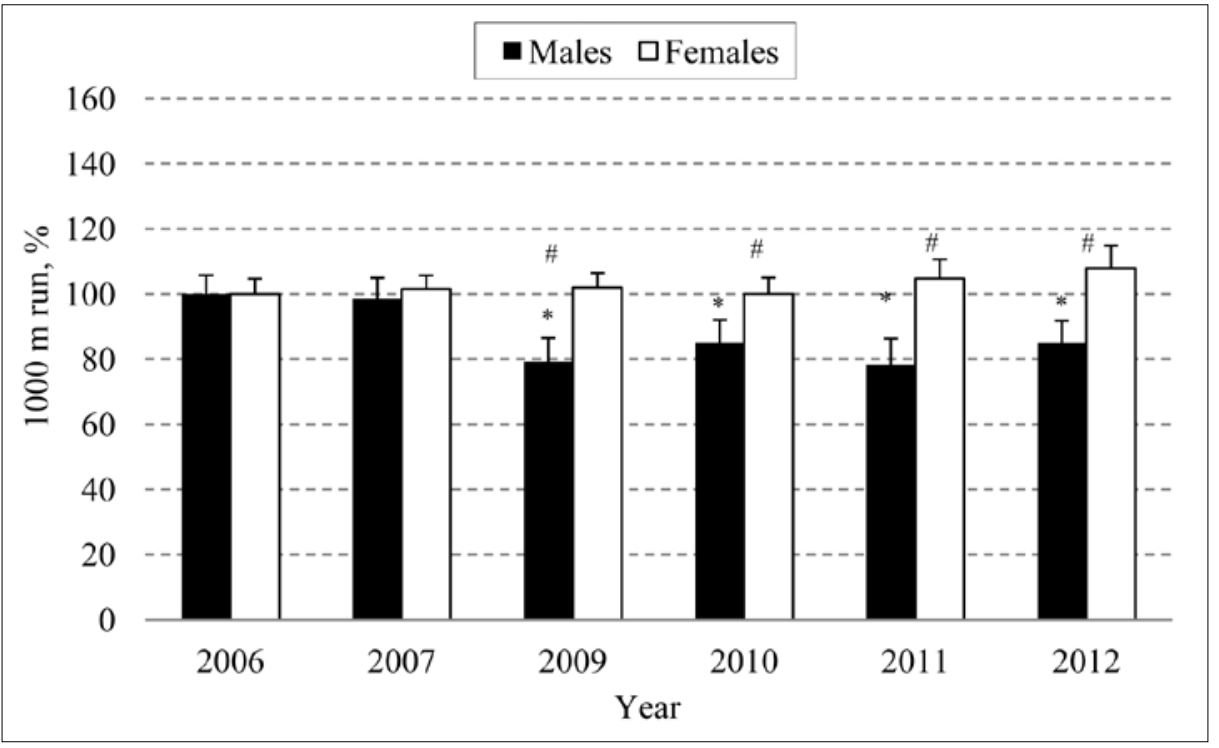

Figure 4. 1000 meter run test results of males and females

\section{DISCUSSION}

Recently, more researchers raise the hypothesis that increasing the physical activity of the elderly can delay the fatigue originating in central and peripheral nervous systems (Doherty, 2003; Selen et al., 2007; Gates, Dingwell, 2008) For these reasons, we expected to observe the tendencies of variation in the physical capacity of elderly people. However, the results of significantly reduced physical capacity were expressed only in older males, in the balance and 1000 meter run tests $(\mathrm{p}<0.05)$.

Most authors emphasize the significant decline in physical activity in people of all ages (Bouchard, Rankinen, 2001; Doherty, 2003; Fitts, 2008). It is also mentioned that the current working conditions may result in physical capacity reduction, early fatigue, sarcopenia and other senile diseases of a lot of people in future (Warburton, Bredin, 2006; Fitts, 2008; Xu, Murrell, 2008; Stone et al., 2010). The research showed that the problem of balance loss is particularly relevant among the elderly, as the loss of balance increases the risk of falls and, consequently, injuries (Kurz et al., 2013) The cause of falls may appear muscle force that can affect the loss of balance, reaction powers, performance of several tasks simultaneously and poor sleep (Boelens et al., 2013).

Our case proved that the males' balance significantly decreased. The studies identified that elderly people who had had a history of falls with injuries, had greater postural fluctuations than those who experienced falls without injuries, and significantly poorer balance than the senior people with no falling history (Kurz et al., 2013). However, the females' balance during the period resulted in a statistically significant improvement $(p<0.05)$. Therefore, we can assume that changing life conditions (Bouchard, Rankinen, 2001) had no negative impact on the balance of senior women, so they were able to maintain and even improve their postural stability.

The performed study illustrated that the aerobic capacity of elderly men was significantly reduced $(\mathrm{p}<0.05)$. Meanwhile, the women's aerobic capacity during the period remained at a similar level. Many scientists confirm that there is compelling evidence of the effect of physical activity on the prevention of primary and secondary chronic diseases (e. g, cardiovascular disease, diabetes, cancer, hypertension, obesity, depression or osteoporosis), and premature death (Warburton, Bredin, 2006; Xue et al., 2012; Dale et al., 2013; Hobbs et al., 2013). One of the most important indicators of physical capacity demonstrating the cardiovascular condition is aerobic capacity. According to the researchers, there is a direct correlation between physical activity and health, and thus, increasing physical activity, aerobic and working capacity would increase as well as improve general health status (Warburton, Bredin, 2006). Based on our study data, the males' aerobic capacity was significantly decreased during the research period, but it was a noticeable improvement in the results of sit-ups and flexibility $(\mathrm{p}<0.05)$. 
Our results confirm the statements made by M. F. Roma et al. (2013) that the nature of aerobic exercise does not have a significant impact on the older people's flexibility. Meanwhile, strength training can have a significant impact on the improvement of flexibility (Roma et al., 2013). While the aerobic capacity of elderly females remained unchanged during the period a significant improvement was noticed in the results of sit up test $(\mathrm{p}<0.05)$. Despite the changes in trunk flexor muscle strength, females' flexibility results showed no improvement changes. These results do not coincide with the previously mentioned statements by the scientists M. F. Roma et al. (2013). However, the results confirm the statement by S. T. Sims et al. (2013) that aerobic capacity is not related to the elasticity of the muscle mass tending to decline among older women despite the level of physical activity.

According to the author Z. Milanović et al. (2013) physical capacity decline occurs equally in males and females, and this decline is related to the ageing process. According to the author, the differences among the elderly may be due to an individual's upper and lower limb muscle strength decrease, and the changes in body fat layer, flexibility, mobility and endurance (Milanović et al., 2013). Our survey data noted that most of the physical capacity tests (sit-ups, balance, and 1000 m running) were more significantly important for females than males.
The dynamics of result variation suggests that the physical activity and lifestyle of elderly males is insufficient to maintain the required physical capacity. Meanwhile, the physical activity of the studied elderly females was sufficient to maintain the required level of physical fitness in spite of the changing living conditions during the prolonged period of time. It is well known that both aerobic and strength training exercises can significantly improve the fitness of the elderly and healthrelated factors despite the age-related processes (Romero-Arenas et al., 2013). Taking into account the importance of physical capacity for life quality at old age, it is important to continue to record the physical capacity of the elderly and to monitor changes in parameters and their effect on the quality of life and old age.

\section{CONCLUSIONS AND PERSPECTIVES}

The balance and aerobic capacity of the elderly males have significantly decreased, whereas flexibility improved $(p<0.05)$. The trunk flexion muscle strength and balance of elderly females have significantly increased $(p<0.05)$. The genderspecific analysis showed that the majority of older females' physical capacity results statistically significantly improved more than those of males $(\mathrm{p}<0.05)$.

\section{REFERENCES}

Boelens, C., Hekman, E. E, Verkerke, G. J. (2013). Risk factors for falls of older citizens. Technology and Health Care, Sep 27 [Epub ahead of print].

Bouchard, C., Rankinen, T. (2001). Individual differences in response to regular physical activity. Medicine and Science in Sports and Exercise, 33 (6), 46-51.

Dale, C. E., Bowling, A., Adamson, J. et al. (2013). Predictors of patterns of change in health-related quality of life in older women over 7 years: Evidence from a prospective cohort study. Age and Ageing. 3 (42), 312318.

Doherty, T. J. (2003). Invited review: Aging and sarcopenia. Journal of Applied Physiology, 95 (4), 1717-1727.

Fitts, R. H. (2008). The cross-bridge cycle and skeletal muscle fatigue. Journal of Applied Physioloy, 104 (2), 551-558.

Gandevia, S. C. (2001). Spinal and supraspinal factors in human muscle fatigue. Physiological Reviews, 81 (4), 1725-1789.
Gates, D. H., Dingwell, J. B. (2008). The effects of neuromuscular fatigue on task performance during repetitive goal-directed movements. Experimental Brain Research, 187 (4), 573-585.

Hobbs, N., Godfrey, A., Lara, J. et al. (2013). Are behavioral interventions effective in increasing physical activity at 12 to 36 months in adults aged 55 to 70 years? A systematic review and meta-analysis. BMC Medicine, 1 (11), 75.

Kowalski, K., Rhodes, R., Naylor, P. J., Tuokko, H., MacDonald, S. (2012). Direct and indirect measurement of physical activity in older adults: A systematic review of the literature. The International Journal of Behavioral Nutrition and Physical Activity, 9, 148.

Kurz, I., Oddsson, L., Melzer, I. (2013). Characteristics of balance control in older persons who fall with injury: A prospective study. Journal of Electromyography and Kinesiology, May 10 [Epub ahead of print].

Milanović, Z., Pantelić, S., Trajković, N. et al. (2013). Age-related decrease in physical activity and functional 
fitness among elderly men and women. Journal of Clinical Interventions in Aging, 8, 49-56.

Roma, M. F., Busse, A. L., Betoni, R. A. et al. (2013). Effects of resistance training and aerobic exercise in elderly people concerning physical fitness and ability: A prospective clinical trial. Einstein (San Paulo, Brasil), 11 (2), 153-157.

Romero-Arenas, S., Martínez-Pascual, M., Alcaraz, P. E. (2013). Impact of resistance circuit training on neuromuscular, cardiorespiratory and body composition adaptations in the elderly. Aging and Disease, 4 (5), 256-263.

Selen, L. P., Beek, P. J., van Dieën, J. H. (2007). Fatigueinduced changes of impedance and performance in target tracking. Experimental Brain Research, 181 (1), 99-108.

Sims, S. T., Kubo, J., Desai, M. et al. (2013). Changes in physical activity and body composition in postmenopausal women over time. Medicine and Science in Sports and Exercise, 45 (8), 1486-1489.
Stone, M. B., Edwards, J. E., Huxel, K. C. et al. (2010). Threshold frequency of an electrically induced cramp increases following a repeated, localized fatiguing exercise. Journal of Sports Science, 28 (4), 399-405.

Volbekienè, V., Kavaliauskas, S. (2002). EUROFITAS. 2-asis pat. ir papild. leidimas. Vilnius: Lietuvos sporto informacijos centras.

Warburton, D., Bredin, S. (2006). Health benefits of physical activity. Canadian Medical Association Journal, 7 (175), 773-776.

Xue, Q. L., Bandeen-Roche, K., Mielenz, T. J. et al. (2012). Patterns of 12-year change in physical activity levels in community-dwelling older women: Can modest levels of physical activity help older women live longer? American Journal of Epidemiology, 6 (176), 34-43.

$\mathrm{Xu}$, Y., Murrell, G. A. (2008). The basic science of tendinopathy. Clinical Orthopaedics and Related Research, 466 (7), 1528-1538.

\title{
PAGYVENUSIŲ ŽMONIŲ FIZINIO PAJĖGUMO RODIKLIŲ KAITA
}

\author{
Lina Kreivėnaitė, Vytautas Streckis, Kristina Visagurskienė, \\ Alfonsas Buliuolis, Asta Lileikienè \\ Lietuvos sporto universitetas, Kaunas, Lietuva
}

\section{SANTRAUKA}

Tyrimo pagrindimas ir hipotezé. Didesnis fizinis pajėgumas gali sukelti bendros pagyvenusių žmonių sveikatos gerejjimą. Autorių nuomone, įvairaus amžiaus žmonių fizinis aktyvumas ir pajėgumas mažejja. Taigi svarbu įvertinti ivvairaus amžiaus žmonių fizini pajègumą ir skatinti juos gerinti gyvenimo kokybę sveikai gyvenant. Hipotezė: tiriamuoju laikotarpiu bus pastebimas ryškus pagyvenusių žmonių fizinio pajègumo mažejjimas.

Tikslas - nustatyti pagyvenusių žmonių fizinio pajègumo rodiklių kaitą.

Metodai. Duomenų analizei pasirinkti 60-69 m. amžiaus vyrai ir moterys. Tiriamoji imtis $\mathrm{n}=244$. Buvo analizuoti antropometriniai duomenys, „Liemens lenkimo“, „Sèstis ir gultis“, „Pusiausvyros“ ir „1000 metrų bėgimo“ testų rezultatai. Atliekant fizinio pajègumo testus buvo vadovaujamasi Eurofito metodika. Duomenų analizei atlikti naudoti aprašomosios statistikos metodai.

Rezultatai. Tiriamuoju laikotarpiu pagyvenusių vyrų kūno pusiausvyra statistiškai reikšmingai suprastejjo $(43,8 \% ; p<0,05), 20,8 \%$ sumažèjo jų aerobinis pajègumas $(\mathrm{p}<0,05)$, tačiau statistiškai reikšmingai pagerèjo $(16,5 \% ; p<0,05)$ lankstumas. Pagyvenusių moterų liemens lenkiamujų raumenų pajègumas statistiškai reikšmingai pagerèjo 39,3\%, pusiausvyra - 18,1\% (p <0,05). Analizuojant rezultatus lyčių požiūriu paaiškèjo, kad pagyvenusių moterų pusiausvyra, liemens lenkiamujų raumenų ir aerobinis pajègumas gerejo statistiškai reikšmingai daugiau nei vyru $(p<0,05)$. Visgi vyrų lankstumo kaita tiriamojo laikotarpio pabaigoje buvo didesnè nei moteru $(p<0,05)$.

Aptarimas ir išvados. Pagyvenusių vyrų pusiausvyra ir aerobinis pajėgumas statistiškai reikšmingai sumažèjo, lankstumas - pagerèjo. Statistiškai reikšmingai padidèjo pagyvenusių moterų liemens lenkiamujų raumenų pajègumas ir pusiausvyra. Lyginant tiriamuosius lyčių požiūriu nustatyta, kad daugumos pagyvenusių moterų fizinio pajėgumo rezultatai statistiškai reikšmingai pagerèjo labiau nei vyrų.

Raktažodžiai: fizinis pajègumas, pagyvenę žmonès, Eurofitas. 